\title{
IS HET BEGRIP ,.VERTROUWEN" IN LIMPERG'S LEER OVER DE GRONDSLAGEN VAN DE ACCOUNTANTS-CONTROLE EEN ETHISCH BEGRIP?
}

\author{
door Dr L. H. Belle
}

In het Octobernummer van dit blad komt onder dezelfde titel een artikel voor van Drs Slot. Het artikel wijst op een passage uit een opstel van mijn hand in het V.A.G.A.-Gedenkboek, die verduidelijking verdient en thans door mij kan worden gegeven.

Ik beschreef in bedoeld artikel zoals de titel aanduidt „Hoofdtrekken der ontwikkeling van de accountantscontrole" in de laatste vijf en twintig jaar. Zo vermeldde ik ook de leer van het gewekte vertrouwen.

,Even later - zo memoreerde ik — werd de theorie verrijkt met het befaamde referaat van Prof. Dr Limperg voor het internationaal accountantscongres van 1926. Men mag, zoals ondergetekende, het uit een zuiver theoretisch oogpunt niet eens zijn met de opzet ervan, erkend dient echter te worden, dat bedoelde congres-rede een juiste analyse gaf van doel en betekenis van de accountantsverklaring". De leer zelf is voldoende bekend en het viel buiten het bestek van mijn opstel om haar nader uit een te zetten. Waar ik, gelijk in accountantskringen óók bekend is, met betrekking tot de rol van het vertrouwenselement ten dele een afwijkend inzicht heb, trachtte ik in het kort de overeenstemming en het verschil te formuleren.

De opmerking van de Heer Slot dat ik een eigen interpretatie van Limperg's leer bestrijd is dus eigenlijk onjuist. Ik gaf een toelichting op mijn eigen visie van de rol van het vertrouwenselement in de theorie der accountantscontrole, ik beschreef dus niet de vertrouwensleer (v. Limperg). doch mijn eigen zienswijze. Ik ga thans dieper op het probleem in dan in het kader van mijn opstel in het V.A.G.A. Gedenkboek mogelijk was.

In zijn referaat getiteld „De betekenis van de accountantsverklaring in verband met de verantwoordelijkheid van de accountant", lanceert Prof. Limperg de bekende stelling: „De verklaring mag geen groter vertrouwen wekken dan gerechtvaardigd wordt door het voorafgegane onderzoek". Op grond hiervan keert hij zich, daarbij zijn bekende theorie ontwikkelende, tegen het kwaad van de verklaring met een voorbehoud, nl. een voorbehoud dat de leemte in het gehouden onderzoek vooropstelt en deze dus subjectief bepaalt. Dit deel van de met het oog op de practijk geconcipiëerde leer heb ik van meet af aan aangehangen. De moeilijkheid schuilt hierin, dat ik het woord ,vertrouwen" in ethische zin opvat, terwijl Prof. Limperg verklaart, dat zijn leer geen ethisch element inhoudt. In zijn bekende M.A.B. artikelen lichtte hij nader toe waarom het woord vertrouwen in zijn leer geen ethische betekenis heeft. Het dient opgevat te worden als ,een stellige en min of meer gegronde verwachting". Ook na deze toelichting kan ik er geen andere dan een ethische inhoud aan verbinden; naar mijn mening zijn vertrouwen en verwachting hier stamverwante begrippen ${ }^{1}$ ). Dit is de reden, dat ze naast en door elkaar gebezigd worden. Het lijkt mij voor de accountant onmogelijk, het referaat zonder projectie tegen een achtergrond van daadwerkelijke toepassing te lezen. In dit opzicht bevat het m.i. een ethisch element, een moraal

1) De verwachting bestaat immers doordat men vertrouwen stelt in de vakkundigheid van de accountant; de verwachting bestaat dus niet zonder het vertrouwen, zij vloeit daaruit voort. 
en is het althans (mede) met ethische bedoeling geschreven. Wat ik "wit" zie, kan ik moeilijk , zwart" noemen.

Ik ben ten aanzien van de begripsformulering niet over één nacht ijs gegaan. Reeds in mijn "Grondslagen der Accountancy" (1931) onderzocht ik de inhoud van begrippen als verantwoordelijkheid, vertrouwen enz. Op gezag van een erkend wijsgeer als Kant, concludeerde ik dat aan de verhouding tussen de mensen als mens tot mens (ethische betrekking) een andere maatstaf moet worden aangelegd dan aan de verhouding tussen de mensen als sociale gegevens. Deze laatste verhouding (waartoe ook de werkzaamheid van de public-accountant gerekend kan worden) is van een relatief karakter. Dit sluit echter niet uit, dat er een ethische kant aan het maatschappelijk handelen (van de accountant) is. Integendeel, er is een belangrijke ethische zijde te ontwaren in zijn optreden als „vertrouwensman" (mandataris) van het maatschappelijk verkeer. Het is mogelijk, dat Prof. Limperg aan de verhouding van "mens tot mens" denkt, als hij het over ethiek heeft; in een van zijn artikelen ${ }^{2}$ ) schrijft hij: ,,als men van iemand zegt, dat hij te vertrouwen is, dan schrijft men hem een goede karaktereigenschap toe". Welnu, ons interesseren niet zozeer de goede karaktereigenschappen van de accountant als mens, maar in de eerste plaats het goede vakmanschap, de objectiviteit en integriteit van de accountant als "sociaal gegeven", als vertrouwensman van het maatschappelijk verkeer. Dat is óók een ethische betrekking, maar van an dere orde, in een andere sfeer (nl. het economische leven). Het resultaat is in elk geval dat Prof. Limperg een vertrouwensleer zonder en ik een leer met ethische inhoud voorsta. Uiteindelijk doet het er weinig toe, of men het woord "vertrouwen", al dan niet een ethisch begrip noemt. De inhoud van dit begrip wordt, geloof ik, door geen enkele accountant in zijn beroepsuitoefening misverstaan. $\mathrm{Nu}$ is het mijn opvatting, dat het begrip ,"vertrouwen" géén, althans geen directe invloed heeft op de taakbepaling en taakuitvoering van de accountant, het speelt daarbij een passieve tol; de accountant richt zich naar het positieve doel van de opdrachten. Ik kom hier straks nog nader op terug.

In het licht van het bovenstaande beschouwd, zal het de Heer Slot duidelijk zijn dat ik in de eerste plaats mijn eigen opvattingen, weergeef, waar ik zeg:

„Als zedeleerkundige leidraad voor de beroepsuitoefening van de in,dividuele accountant is het referaat in de afgelopen 25 jaar van grote .,betekenis geweest. De handelsmoraal verbiedt reeds de eenvoudige "marktkoopman om ",knollen voor citroenen" te verkopen; zoveel temeer .geldt het voor de public-accountant, dat hij bij zijn taakvervulling het in ,hem gestelde vertrouwen dient te honoreren. Het is daarom zijn be,,roepsplicht te waarborgen dat zijn verklaringen goud gerand zijn, dit ,verwacht men van hem op grond van zijn deskundigheid en integriteit, ,terwijl zijn zelfstandigheid de voorwaarde voor een objectief oordeel „,schept. Dit alles mag evenwel nog geen reden zijn om bij de ontwik,keling der theorie aan de factor vertrouwen een autonome taakbepalende „,rol toe te kennen; die taak en omvang worden logisch slechts bepaald ",door de concrete doelstelling."

Misschien kan, wat ik nu nog aan mijn opmerkingen toevoeg, de Heer Slot verder op weg helpen mij beter te begrijpen. Als ik zeg dat taak en

2) Zie 25 jaar M.A.B. blz. 240.

m a b blz. 430 
omvang logisch slechts bepaald worden door de concrete doelstelling, dan bedoel ik hier het volgende mee. Als een accountant als deskundig vertrouwensman de juistheid van een jaarrekening moet certificeren, de overname-waarde van een zaak moet bepalen, de goodwill moet berekenen, de waarde van aandelen moet bepalen, een crediet-onderzoek moet instellen, etc., etc., dan zal hij als deskundige ten aanzien van elk der vorenbedoelde opdrachten weten welke controlemaatregelen, welke middelen, hij in elk der gevallen moet aanwenden om tot het gewenste resultaat te komen c.q. om het gestelde doel te bereiken. De Heer Slot nu meent, dat het vertrouwen ,de verwachting ten aanzien van de te verkrijgen zekerheid, in principe wel degelijk betekenis heeft voor de bepaling van de doelstelling en daarmede voor de omvang van de te verrichten werkzaamheden". Dit is wel een heel vage formulering! Als de Heer Slot met "te verkrijgen zekerheid" bedoelt de zekerheid met betrekking tot de juistheid der jaarrekening, dan is dit de doelstelling zelve; zijn stelling is dan zinloos. Hoe dan ook, de "verwachting" heeft naar mijn mening geen, althans geen directe betekenis voor de doelstelling en daarmee voor de omvang van de te verrichten werkzaamheden, en wel om de eenvoudige reden, dat de doelstellingen uit de behoeften van het economische leven zelf voortvloeien, als een origineel concreet gegeven. Zo b.v. het nut van de vakkundige beoordeling betreffende de juistheid der jaarrekening. De accountant richt hiernaar zijin controle-arbeid. Houdt hij zich daarbij aan de gangbare opvattingen omtrent de controle techniek, zo kan zijn arbeid doeltreffend genoemd worden; als dan is het economisch nut der controle bereikt, terwijl hij daarmede tevens en van zelf het in hem gestelde vertrouwen, de gekoesterde verwachting, honoreert; dit laatste is (wat ik noem) de ethische kant van het onderhavige economische probleem. $Z_{\mathrm{ij}}$ is niet oorzakelijk, niet de arbeidsomvang bepalend, doch nevenzakelijk. Op die omvang is o.m. wèl van invloed de toestand van de betreffende administratie, de organisatie van de interne controle incluis. Blijft de accountant met zijn arbeid onder de geldende normen, zo is zijn controle ondoeltreffend; dan wordt het beoogde economisch nut niet bereikt, terwijl tevens het in hem gestelde vertrouwen wordt beschaamd: hier wordt de passieve factor pas actief. Het is ter bestrijding van dit euvel, dat een vertrouwensleer ${ }^{3}$ ), maar dan een ,ethische", van belang is, welker normatieve kern ik met Prof. Limperg gaarne als volgt redigeer: ,.de accountant is verplicht om zijn arbeid zo te verrichten, dat hij de verwachtingen, welke hij opwekt, niet beschaamt en omgekeerd, de accountant mag geen grotere verwachtingen opwekken dan door de verrichte arbeid gerechtvaardigd wordt". Een a-ethische vertrouwenstheorie, dus zonder een ethisch element, is naar mijn mening bloedarm, heeft eigenlijk geen reden van bestaan.

De Heer Slot schijnt te menen, dat de M.A.B. artikelen van Prof. Limperg mij onberoerd hebben gelaten. Ik kan hem op dit punt geruststellen; ook ik ben bewust en onbewust daardoor beïnvloed. Zodoende is er veel wat mij aan deze Meester bindt, die binding blijkt echter nog steeds niet restloos te zijn.

$\mathrm{Na}$ het vorengaande kan naar ik meen de door de Heer Slot als titel voor zijn opstel gekozen vraag, of het begrip ,.vertrouwen" in Limperg's

3) Een leer is normen, regels gevend, en werkt daardoor in dit geval ook ethisch uit (Gij zult niet ......); waar Prof. Limperg een andere strekking geeft aan het begrip vertrouwen resp. verwachting, is het wellicht juister om van de vertrouwenstheorie van Limperg te spreken. 
leer een ethisch begrip is, als volgt beantwoord worden: dat hangt af van de opvatting, welke men over het begrip ethiek heeft.

Behalve critiek, heeft de Heer Slot in enkele regels een verduidelijking van de door hem aangehangen leer gegeven:

„Vertrouwen wil hier niet zeggen - aldus Drs Slot —, dat men ver"trouwt, verwacht, dat de accountant zijn taak naar behoren zal vervullen, ",doch dat men verwacht een bepaalde zekerheid te zullen verkrijgen".

Het lijkt mij ongerijmd toe, dat men denkende over de accountant als vertrouwensman van het maatschappelijk verkeer, zijn taak en verantwoordelijkheden, etc., aan het woord ",vertrouwen" niet mag verbinden het vertrouwen, de verwachting, dat de accountant zijn taak naar behoren zal vervullen. Een leer met zulk een gebruiksaanwijzing is niet bijzonder toegankelijk! Verder commentaar lijkt mij overbodig. 